\title{
DESAIN PENGEMBANGAN KURIKULUM MADRASAH ALIYAH UNGGULAN DI ERA REVOLUSI INDUSTRI 4.0
}

\author{
Mochamad Nurcholiq \\ STAI Ma'had Aly Al-Hikam Malang - Indonesia \\ choliq7791@gmail.com
}

\begin{abstract}
Madrasah Aliyah (Islamic Junior High School) is an educational institution that has specificity in ideas and applications to manifest Islamic values embodied in vision, mission, goals, and educational programs. Madrasah Aliyah graduates are expected not to miss the era of industrial revolution 4.0 which emphasizes the pattern of digital economy, artificial intelligence, big data, robotic, or known as the disruptive innovation phenomenon. Leading graduates of Madrasah Aliyah are prepared to become quality cadres or human resources with high competitiveness. Curriculum design is a core part of education that must have the right guidelines and objectives in accordance with the socio-cultural conditions of the community and keep up with the times like the current of industrial revolution era 4.0.
\end{abstract}

\begin{abstract}
Abstrak
Madrasah Aliyah merupakan lembaga Pendidikan memiliki kekhususan dalam ide dan aplikasi untuk memanifestasikan nilai-nilai Islam yang diwujudkan dalam visi, misi, tujuan, maupun program pendidikan. Lulusan Madrasah Aliyah diharapkan tidak ketinggalan pada era revolusi industri 4.0 yang menekankan pada pola digital economy, artificial intelligence, big data, robotic, atau dikenal dengan fenomena disruptive innovation. Lulusan Madrasah Aliyah unggulan disiapkan menjadi kader atau sumber daya manusia yang berkualitas serta memiliki daya saing yang tinggi. Desain kurikulum merupakan bagian inti dari pendidikan yang harus memiliki pedoman dan tujuan yang tepat sesuai dengan kondisi sosial budaya masyarakat dan mengikuti perkembangan zaman seperti era revolusi industry 4.0 saat ini.
\end{abstract}

Kata Kunci : Pengembangan Kurikulum, Madrasah Aliyah Unggulan, Era Revolusi Industri 4.0.

\section{A. PENDAHULUAN}

Undang-undang RI No. 20 Tahun 2003 tentang Sisdiknas menyebutkan bahwa Pendidikan Nasional berfungsi mengembangkan kemampuan dan membentuk watak serta peradaban bangsa yang bermartabat dalam rangka mencerdaskan kehidupan bangsa, bertujuan 
untuk berkembangnya potensi peserta didik agar menjadi manusi yang beriman dan bertakwa kepada Tuhan Yang Maha Esa, berakhlak mulia, sehat, berilmu, cakap, kreatif, mandiri, dan menjadi warga negara yang demokratis serta bertanggung jawab. ${ }^{1}$

Upaya dan usaha selalu dilakukan oleh pelaku pendidikan demi tercapainya fungsi dan tujuan pendidikan nasional tersebut. Mulai dari perencanaan, pengorganisasian, pengawasan, dan penilaian. Dari sini juga muncul pengelompokan-pengelompokan lembaga pendidikan menjadi jenjang, jenis, dan jenis pendidikan.

Salah satu usaha yang sangat diperlukan dalam merealisasikan fungsi dan tujuan pendidikan nasional tersebut adalah melalui pengembangan lembaga pendidikan yang telah ada. Sedangkan dalam pengembangan sekolah tersebut masih dibutuhkan suatu usaha yang lebih spesifik, yaitu pembentukan kurikulum. Jika kurikulum yang dibentuk sudah mewakili segala aspek yang dibutuhkan, mulai dari hubungannya dengan kurikulum jenjang sebelumnya dan setelahnya, serta adanya link dan match dengan masyarakat sekitar.

Dari sinilah penulis ingin menawarkan beberapa langkah dan desain dalam rangka menemukan sekolah unggulan khususnya Madrasah Aliyah, sehingga pada akhirnya sekolah ini benar-benar menjadi tolok ukur sekolah lainnya.

\section{B. PEMBAHASAN}

\section{Landasan Desain Kurikulum Madrasah Aliyah Unggulan}

Sebelum merencanakan segala sesuatu diperlukan landasanlandasan yang akan mengarahkan kemana kegiatan itu akan berjalan. Begitu juga dalam mendesain kurikulum. Kurikulum sebagaimana yang telah diketahui adalah seperangkat rencana dan pengaturan mengenai isi dan bahan serta cara yang digunakan sebagai pedoman penyelenggaraan kegiatan belajar-mengajar. ${ }^{2}$ Maka dari itu karena kurikulum merupakan inti dari pendidikan dan pengajaran di sekolah, maka kiranya harus memiliki pedoman dan arahan.

Agar sekolah yang akan didirikan menjadi sekolah yang benarbenar unggul dari yang lainnya, maka kurikulum yang dibuatpun juga harus menandakan kualitas yang unggul. D isinilah diperlukan beberapa landasan dalam mendesain kurikulum tersebut. Landasan kurikulum tersebut antara lain; landasan filosofis, landasan sosialbudaya-agama, landasan ilmu pengetahuan teknologi dan seni,

\footnotetext{
1 Undang-undang Republik Indonesia No. 20 Tahun 2003, (Bandung: Citra Umbara, 2003), hal 7.

2 Mudjiono dan Dimyati. 2002. Belajar dan Pembelajaran, (Jakarta: Rineka Cipta, 2002), hal. 267.
} 
landasan kebutuhan masyarakat, serta landasan perkembangan masyarakat.

a. Landasan Filosofis. Segala kehendak yang dimiliki oleh masyarakat merupakan sumber nilai yang memberikan arah pada pendidikan. Dengan demikian pandangan dan wawasan yang ada dalam masyarakat merupakan pandangan dan wawasan dalam pendidikan, atau dapat dikatakan bahwa filsafat yang hidup dalam masyarakat merupakan landasan filosofis penyelenggaraan pendidikan. ${ }^{3}$ Madrasah Aliyah merupakan sekolah yang bernafaskan ajaran agama Islam. Sedangkan ajaran agama Islam sendiri banyak mengarah pada perilaku pemeluknya. Dari sinilah maka landasan filosofis yang berasal dari filsafat masyarakat ini sangat diperlukan. Selain itu landasan kurikulum di Indonesia secara cepat dan tepat kita pastikan, yakni nilai dasar yang merupakan falsafah dalam pendidikan manusia seutuhnya yakni Pancasila.

b. Landasan sosial-budaya-agama. Realitas sosial-budaya-agama yang ada dalam masyarakat merupakan bahan kajian pengembangan kurikulum untuk digunakan sebagai landasan mendesain kurikulum. Sebagaimana yang saat ini dijadikan rujukan oleh Pendidikan Nasional, maka masyarakat selaku pengguna lulusan dimasukkan sebagai sumber utama penyusunan desain kurikulum. Langkah ini penting, sebab masyarakat adalah sumber input untuk bahan analisis formulasi umum tujuan pembelajaran. ${ }^{4}$ Masalah sosial-budaya-agama tidak lepas dengan perilaku masyarakat, khususnya masyarakat sekitar sekolah seperti wali murid, tokoh masyarakat yang peduli terhadap Pendidikan, dan pemangku kebijakan dalam suatu daerah. Apalagi dengan Madrasah Aliyah yang bernafaskan Islam, harus menjadikan landasan agama ini sebagai landasan awal.

c. Landasan ilmu pengetahuan teknologi dan seni. Dalam menghadapi perkembangan zaman yang begitu cepat. Kiranya pelaku pendidikan harus siap dengan komponen-komponen yang bisa digunakan untuk menjawab tantangan-tantangan ke depan. Masyarakat ke depan adalah masyarakat global di era globalisasi. Mengingat pendidikan merupakan upaya penyiapan siswa menghadapi perubahan yang semakin pesat, termasuk di dalamnya perubahan ilmu pengetahuan, teknologi, dan seni, maka pendesainan kurikulum haruslah berlandaskan ilmu

\footnotetext{
3 Mudjiono dan Dimyati. 2002. Belajar dan Pembelajaran, hal. 269.

${ }^{4}$ Ariatmi, SZ dan Prabawa, AH. Paradigma Pengembangan Kurikulum Pendidikan Tinggi tahun 2000. (Surakarta: UMS, 2000), hal. 80.
} 
pengetahuan, teknologi, dan seni. ${ }^{5}$ Dengan menjadikan ilmu pengetahun dan teknologi sebagai landasan berarti ke duanya juga akan dijadikan bahan penyelesainan masalah pendidikan. Hal ini disebabkan perkembangan budaya yang sejajar dengan perkembangan ilmu pengetahuan dan teknologi.

d. Landasan kebutuhan masyarakat. Sekolah menengah atas/ Madrasah Aliyah adalah sekolah lanjutan dari sekolah menengah pertama. Karena sudah menjadi manusia yang dewasa, maka lulusannya pun juga harus sudah memiliki kompetensikompetensi yang diperlukan oleh user. Belum lagi dalam pengembangan pendidikan nasional, yang terkenal dengan sebutan strategi Link and Match (keterkaitan dan kesepadanan) seperti yang ungkapkan oleh Wardiman Djojonegoro. ${ }^{6}$ Lebih lanjut dikatakan bahwa pemahaman utuh tentang kebijakan Link and Match meliputi tiga perpektif, yaitu: 1) tempat, yakni mengaitkan tuntutan kebutuhan pembangunanyang didasarkan pertimbangan lokal, wilayah, nasional, dan global; 2) waktu, yakni untuk menjawab tantangan-tantangan masa kini dan mengantisipasi secara proaktif tuntutan masa depan dalam konteks perubahan yang berlangsung amat cepat; dan 3) ranah (domain) pendidikan, yakni kebijakan ini bukan hanya terkait dengan ilmu pengetahuan dan keterampilan semata, tetapi juga wawasan, nilai, sikap dan mentalitas, serta prilaku yang diperlukan dalam kehidupan lingkungan. Dari ungkapan ini jelas bahwa dalam mendesain kurikulum tidak lepas dari lingkungan (tempat dan waktu) di mana sekolah akan didirikan.

e. Landasan perkembangan masyarakat. Perkembangan ilmu pengetahuan selalu berkembang dan berimplikasi pada perkembangan budaya masyarakat. Pendesainan kurikulum kiranya harus melihat faktor perkembangan masyarakat ini, sebab di sana akan terjadi sinkronisasi antara kebutuhan masyarakat sekarang dengan kurikulum yang direalisasikan. Selain penguatan bidang agama di Madrasah Aliyah, ilmu-ilmu lain yang sedang marak dan berkembang juga harus diperkenalkan, pada akhirnya lulusan Madrasah Aliyah tidak ketinggalan informasi dengan adanya perkembangan yang sangat pesat ini. Saat ini masuk era era revolusi industri 4.0, yakni menekankan pada pola digital economy, artificial intelligence, big data, robotic, atau dikenal dengan fenomena disruptive

5 Mudjiono dan Dimyati. 2002. Belajar dan Pembelajaran, hal. 271.

6 Muhaimin. Arah Baru Pengembangan Pendidikan Islam: Pemberdayaan, Pengembangan Kurikulum hingga Redefinisi Islamisasi Pengetahuan. (Bandung: Nuansa, 2003), hal. 153. 
innovation..$^{7}$ Fenomena ini berdampak pada institusi Pendidikan tidak terkecuali Madrasah Aliyah. Bagaimana lulusan Madrasah Aliyah menjadi kader atau sumber daya manusia yang siap berkualitas punya daya saing yang tinggi.

\section{Sekolah Unggulan dan Madrasah Aliyah Unggulan}

Unggul diartikan sebagai pioner atau pemimpin. Unggul adalah lebih tinggi (pandai, baik, cakap, kuat, awet, dan sebagainya) daripada yang lain-lain; ${ }^{8}$ Sekolah unggulan berarti sekolah yang keberadaannya dipandang sebagai panutan bagi yang lain. Segala aktivitasnya dapat dijadikan patokan dan panutan bagi kegiatan pada lembaga lain.

Dalam konteks Madrasah Aliyah mempunyai karakteristik tersendiri jika dibandingkan dengan SMA. Madrasah Aliyah mempunyai ide dan niatan untuk memanifestasikan atau mengejewentahkan nilai-nilai Islam, yang diwujudkan dalam visi, misi, tujuan maupun program pendidikan. Sebagaimana yang dilansir dalam Undang-undang SISDIKNAS No. 20 Tahun 2003 bahwa tujuan pendidikan untuk mendapatkan manusia-manusia yang berwatak mulia serta Iman kepada Tuhan Yang Maha Esa dengan didasari oleh keilmuan dan kecakapan serta tanggung jawab kepada Nusa dan Bangsa.

Maka dari itu Madrasah Aliyah seharusnya bisa menjaga kekhasannya dalam pendalaman agama Islam dengan tidak mengesampingkan ilmu yang lain. Untuk merealisasikan tujuan dan harapan tersebut perlu kiranya disediakan sarana dan prasarana yang mendukung keberhasilannya. Dari faktor pendukung tersebut antara lain:

a. Adanya SDM yang memadahi.

b. Adanya kurikulum yang integral/ Integrated Curriculum.

c. Adanya follow up atas apa yang telah direncanakan.

\section{Model Desain kurikulum Madrasah Aliyah Unggulan}

Kegiatan membuat Madrasah Aliyah yang berkualitas memerlukan suatu model pendesainan kurikulum yang dijadikan landasan teoritis untuk melaksanakan kegiatan tersebut. Banyak terdapat model-model desain kurikulum yang ditawarkan oleh para pakar pendidikan demi terwujudnya sekolah yang berkualitas, antara lain;

a. Separated Subject Curriculum

7 http://sumberdaya.ristekdikti.go.id/index.php/2018/01/30/era-revolusi-industri4-0-saatnya-generasi-millennial-menjadi-dosen-masa-depan/ 8 https://kbbi.web.id/unggul 
Dalam desain ini, kurikulum mata pelajaran dipisah, bahkan kurikulumnya dimaksudkan dalam bentuk mata pelajaran yang terpisah-pisah yang kurang mempunyai keterkaitan dengan mata pelajaran lainnya. Konsekuensinya adalah anak didik diharuskan mengambil mata pelajaran semakin banyak. ${ }^{9}$ Dan model ini disebut dengan model lama, yang mana sudah digunakan oleh orang Yunani dan kemudian Romawi yang mengembangkan Trivium dan Quadrivium.

b. Correlated Curriculum

Model ini adalah kebalikan dari model sebelumnya, yang mana dalam model ini kurikulum yang ada disatukan dalam bentuk tujuan. Satu pelajaran dengan pelajaran yang lainnya dihubungkan sehingga ruang lingkup bahan tercakup semakin luas.

Dalam menghubungkan satu mata pelajaran dengan lainnya terdapat korelasi yang kiranya perlu diperhatikan;

1) Korelasi insidental/ aksional. Korelasi ini datang secara tiba-tiba atau sekonyong-konyong datang ketidak dalam pengajaran.

2) Korelasi sitematis. Kalau yang pertama tanpa ada rencana, pada korelasi ini sengaja direncanakan oleh guru tentang hubungan atar mata pelajaran.

3) Korelasi normatif. Korelasi antar pelajaran dengan banyak menekankan pada aspek moral dan etika. ${ }^{10}$

c. Learner-Centered Design

Learner-Centered Design ini lebih menekankan pada peserta didik. Sedangkan guru hanya berperan sebagai pencipta situasi belajar mengajar, mendorong dan memberikan bimbingan sesuai dengan kebutuhan peserta didik.

d. Problem Centered Design, dan

Pemusatan pada masalah yang sedang terjadi merupakan titik inti dari pembentukan kurikulum. Model ini berangkat dari pemahaman bahwa manusia adalah makhluk sosial yang tidak lepas dari permasalahan yang memerlukan pemecahan. Titik fokus kurikulum ini adalah bagaimana dapat menjawab dan menjelaskan permasalahan sosial yang sedang terjadi.

e. Integrated Curriculum. ${ }^{11}$

Kurikulum terpadu merupakan salah satu produk usaha pengintegrasian bahan pelajaran dari berbagai macam

9 Idi, Abdullah. Pengembangan Kurikulum. (Jakarta: GMP, 1999), hal 27.

10 Sujana, Nana. Dasar-dasar Proses Belajar Mengajar. (Bandung: Sinar Baru, 1989), hal, 17.

11 Idi, Abdullah. Pengembangan Kurikulum, hal. 27. 
JURNAL PIWULANG, Vol. I No. 2 Maret 2019, 208-222

pelajaran. Integrated curriculum ini di desain dengan memusatkan pelajaran pada masalah tertentu yang memerlukan solusi dengan materi atau bahan dari berbagai disiplin atau mata pelajaran. ${ }^{12} \backslash$

\section{Desain Kurikulum Madrasah Aliyah Unggulan yang Ideal}

Suatu yang sangat tidak wajar kalau kita berharap agar siswa menguasai segala macam ilmu pengetahuan. Akal pikiran manusia sangat terbatas, selain terbatas oleh umur, otak, juga karena kondisi dan situasi. Siswa pada sekolah Madrasah Aliyah adalah para siswa pada tarap menengah, yang mana mereka mulai dapat mengembangkan logika-nya dalam mencerna segala konten/ isi dari mata pelajaran yang didapat.

Kalaulah kiranya ingin dibuat Madrasah Aliyah Unggulan yang mana keilmuan agama tidak diragukan sedangkan ilmu umumnya tidak di tinggalkan, maka perlu didesain suatu perangkat yang dapat mengantarkan kepada tujuan tersebut. Salah satu perangkat tersebut adalah Kurikulum yang Terpadu.

Dalam mendesain kurikulum tidak lepas dari tujuan yang telah dicanangkan dalam UU SISDIKNAS, bahwa untuk kurikulum pendidikan dasar dan menengah wajib memuat:

a. pendidikan agama;

b. pendidikan kewarganegaraan;

c. bahasa;

d. matematika;

e. ilmu pengetahuan alam;

f. ilmu pengetahuan sosial;

g. seni dan budaya;

h. pendidikan jaMAni dan olahraga;

i. keterampilan/kejuruan; dan

j. muatan lokal. ${ }^{13}$

Kesepuluh macam ilmu pengetahuan diatas merupakan mata pelajaran umum yang harus dimasukkan dalam kurikulum. Dalam mendesain kurikulum ini juga tidak terlepas dengan kebijakan terbaru yang berkenaan dengan Kurikulum Berbasisi Kompetensi. Sampai dengan tahun 1993/1994, pada Madrasah Aliyah diberlakukan kurikulum 1984. Dalam kurikulum 1984 tersebut, pada Madrasah Aliyah dikembangkan dalam 5 jenis program pilihan, yang dapat dikelompokkan menjadi dua, yaitu:

12 Idi, Abdullah. Pengembangan Kurikulum, hal. 31.

13 Undang-undang Republik Indonesia No. 20 Tahun 2003, hal 25-26. 
a. Program Pendidikan Ilmu-ilmu Agama, dengan perbandingan jam pelajaran agama: pelajaran umum 98:142 atau 41\%:59\%. Dalam perkembangannya, kurikulum ini dipandang kurang memadai sebagai program yang menyiapkan siswa untuk melanjutkan pendidikannya ke Perguruan Tinggi Agama. Dari sinilah muncul ide yaitu dengan adanya MAPK (Madrasah Alilyah Program Khusus) dengan perbandingan jam pelajaran agama: pelajaran umum adalah 70\%:30\%.

b. Program yang sama dengan MA (Ilmu-ilmu Fisik, Ilmu Biologi, Ilmu-ilmu Sosial, dan Pengetahuan Budaya) dengan intensitas pendidikan agama lebih tinggi dibanding di MA (jam pelajaran agama: pelajaran umum 56:184 atau 23\%:77\%.14

Sedangkan pada tahun 2004 ini akan direalisasikan sistem KBK yang diharapkan para sisiwa memiliki kompetensi pada mata pelajaran masing-masing.

Standar kompetensi yang diharapkan dari para siswa adalah bahwa siswa bukan hanya mendapatkan pengayaan pengetahuan (kognitf) saja melainkan juga mendapatkan pembentukan sikap (afektif) serta pembiasaan (psikomotirik).

Terkait dengan mata pelajaran yang harus dimasukkan dalam Madrasah Aliyah, sesuai dengan ketentukan kurikulum Nasional, maka Madrasah Aliyah memiliki proporsi sebagai berikut:

a. Pendidikan Agama Islam (40\%)

1) Al-Qur'an/ Hadits

2) Keimanan

3) Syari'ah

4) Akhlak

5) Tarikh

b. Pendidikan Umum (60 \%)

1) pendidikan kewarganegaraan

2) bahasa

3) matematika

4) ilmu pengetahuan alam

5) ilmu pengetahuan sosial

6) seni dan budaya

7) pendidikan jaMAni dan olahraga

8) keterampilan/kejuruan; dan

9) muatan lokal

Perimbangan demikian mestinya juga memperhatikan khas dari Madrasah Aliyah yang bersangkutan serta kebutuhan masyarakat

${ }^{14}$ Rahim, Husni. Arah Baru Pendidikan Islam di Indonesia. (Jakarta:Logos, 2001), hal 113. 
setempat. Masyarakat pada hakikatnya mengharapkan Madrasah mampu menyelenggarakan pendidikan agama seratus persen, demikian juga pendidikan umum. Hal ini disebabkan oleh lahirnya UU No. 2 Tahun 1989 tentang Sistem Pendidikan Nasional, di mana madrasah diakui secara juridis sebagai bagian integral dari sistem pendidikan nasional. Dan karenanya, status madrasah mengalami perubahan dari lembaga pendidikan agama menjadi lembaga pendidikan umum berciri khas agama Islam yang harus memasukkan kurikulum umum didalamnya.

Proporsi yang diberikan untuk pendidikan agama Islam terlihat sedikit dan untuk pengetahuan umum banyak. Permasalahan ini sebenarnya agar teori yang didapatkan oleh para siswa sedikit sedangkan perilaku yang diharapkan lebih banyak. Hal ini juga dalam rangka mengoptimalkan aspek afektif dan psikomotorik yang tanpa menafikkan aspek kognitif.

Model Integrated Curriculum ini dipandang lebih baik jika diaplikasikan pada tarap Madrasah Aliyah, dikarenakan keilmuan yang miliki siswa khususnya dalam pengetahuan agama Islam dapat juga dijewentahkan dalam pelajaran lainnya, yaitu melalui sikap dan perilaku yang dimunculkan oleh para siswa. Dan inilah yang diharapkan, pendidikan agama Islam bukan hanya sekedar ilmu tetapi ditampakkan dalam bentuk sikap, perilaku sehari-hari.

Jika dibandingkan dengan Model Tyler, kiranya Integrated Curriculum ini mempunyai persamaan. Karena Tyler memasukkan sumber identifikasi needs dari tiga unsur, yaitu unsur peserta didik, unsur masyarakat pemakai, dan unsur materi pelajaran sendiri. ${ }^{15}$ Pada Madrasah Aliyah tingkat emosional siswa sudah terbentuk, maka dari itu pendidikan agama hanya di alokasikan sebanyak $40 \%$ lalu diimbangi dengan kebutuhan masyarakat yang mana menuntut agar lulusan Madrasah Aliyah juga mempunyai kemampuan ilmu umum, begitu juga tentang materi pelajarannya juga tidak meninggalkan kurikulum yang telah ditentukan oleh Negara.

\section{Kompetensi Lulusan Madrasah Aliyah Unggulan}

a) Kompetensi bahan Kajian Pendidikan Agama Islam

Kompetensi bahan kajian pendidikan Agama Islam adalah Siswa beriman dan bertaqwa kepada Tuhan Yang Maha Esa; berakhlaq mulia/berbudi pekerti luhur yang tercermin dalam kehidupan pribadi, bermasyarakat, berbangsa, dan bernegara; memahami, menghayati, dan mengamalkan ajaran agamanya; serta mampu menghormati agama lain dalam kerangka kerukunan antar umat beragama.

${ }^{15}$ Ariatmi, SZ dan Prabawa, AH. Paradigma Pengembangan Kurikulum..., , hal. 83. 
JURNAL PIWULANG, Vol. I No. 2 Maret 2019, 208-222

Sedangkan kompetensi spesifik pendidikan agama islam dengan landasan Al Qur'an dan Sunnah Nabi saw; siswa beriman dan bertaqwa kepada Allah swt; berakhlaq mulia/berbudi pekerti luhur yang tercermin dalam perilaku sehari-hari dalam hubungannya dengan Allah, sesama manusia, dan alam sekitar; mampu membaca dan memahami Al Qur'an; mampu beribadah dan bermuamalah dengan baik dan benar; serta mampu menjaga kerukunan intern dan antar umat beragama.

\section{b) Standar Kompetensi Dasar Mata Pelajaran}

Kompetensi dasar mata pelajaran berisi sekumpulan kemampuan minimal yang harus dikuasai siswa selama menempuh pendidikan di MA. Kompetensi ini berorientasi pada perilaku afektif dan psikomotorik dengan dukungan pengetahuan kognitif dalam rangka memperkuat keimanan dan ketaqwaan terhadap Tuhan Yang Maha Esa sesuai dengan ajaran Islam. Kemampuan-kemampuan yang tercantum dalam komponen Kemampuan Dasar ini merupakan penjabaran dari kemampuan dasar umum yang harus dicapai di MA, yaitu:

1. Beriman kepada Allah SWT dan lima rukun iman yang lain dengan mengetahui fungsi dan hikmahnya serta terefleksi dalam sikap, perilaku, dan akhlak peserta didik dalam dimensi vertikal maupun horizontal.

2. Dapat membaca, menulis, dan memahami ayat-ayat Al Qur'an serta mengetahui hukum bacaannya dan mampu mengimplementasikan dalam kehidupan sehari-hari.

3. Mampu beribadah dengan baik sesuai dengan tuntunan syari'at Islam baik ibadah wajib maupun ibadah sunnah.

4. Dapat meneladani sifat, sikap, dan kepribadian Rasulullah, sahabat, dan tabi'in serta mampu mengambil hikmah dari sejarah perkembangan Islam untuk kepentingan hidup seharihari masa kini dan masa depan.

5. Mampu mengamalkan sistem mu'amalat Islam dalam tata kehidupan bermasyarakat, berbangsa, dan bernegara.

Seperti tergambar dalam kemampuan dasar umum di atas, kemampuan dasar tiap kelas yang tercantum dalam Standar Nasional juga dikelompokkan ke dalam lima aspek mata pelajaran Pendidikan Agama Islam MA, yaitu: Al Qur'an, Keimanan; Akhlak; Fiqih/Ibadah; dan Tarikh. Berdasarkan pengelompokan per aspek, kemampuan dasar mata pelajaran Pendidikan Agama Islam MA adalah sebagai berikut:

a) Al Qur'an/Al Hadits:

1) Membaca Al Qur'an dengan fasih (tadarrus) (Dilaksanakan pada setiap awal jam pelajaran Pendidikan Agama selama 510 menit). 
2) Membaca dan faham ayat-ayat tentang manusia dan tugasnya sebagai makhluk serta mampu menerapkannya dalam perilaku sehari-hari.

3) Membaca dan faham ayat-ayat tentang prinsip-prinsip beribadah serta mampu menerapkannya dalam perilaku sehari-hari.

4) Membaca dan faham ayat-ayat tentang demokrasi serta mampu menerapkannya dalam perilaku sehari-hari.

5) Membaca dan memahami ayat-ayat tentang kompetisi serta mampu menerapkannya dalam perilaku sehari-hari.

6) Membaca dan memahami ayat-ayat tentang perintah menyantuni kaum lemah serta mampu menerapkannya dalam perilaku sehari-hari.

7) Membaca dan memahami ayat-ayat tentang perintah menjaga kelestarian lingkungan hidup serta mampu menerapkannya dalam perilaku sehari-hari.

8) Membaca dan memahami ayat-ayat tentang anjuran bertoleransi serta mampu menerapkannya dalam perilaku sehari-hari.

9) Membaca dan memahami ayat-ayat tentang etos kerja serta mampu menerapkannya dalam perilaku sehari-hari.

10)Membaca dan memahami ayat-ayat yang berisi dorongan untuk mengembangkan IPTEK serta mampu menerapkannya dalam perilaku sehari-hari.

b) Keimanan/Akidah

1) Beriman kepada Allah dan menghayati sifat-sifat-Nya.

2) Beriman kepada malaikat dan memahami fungsinya serta mampu menerapkan dalam perilaku sehari-hari.

3) Beriman kepada rasul-rasul Allah dan memahami fungsinya serta mampu menerapkan dalam perilaku sehari-hari.

4) Beriman kepada kitab-kitab Allah dan memahami fungsinya serta mampu menerapkan dalam perilaku sehari-hari.

5) Beriman kepada hari akhir dan memahami fungsinya serta mampu menerapkan dalam perilaku sehari-hari.

6) Beriman kepada qadha dan qadar dan memahami fungsinya serta mampu menerapkan dalam perilaku sehari-hari.

c) Syari'ah/Fiqih

1) Memahami sumber-sumber hukum Islam dan pembagiannya.

2) Memahami hikmah shalat dan mampu menerapkannya dalam perilaku sehari-hari.

3) Memahami hikmah puasa dan mampu menerapkannya dalam perilaku sehari-hari. 
JURNAL PIWULANG, Vol. I No. 2 Maret 2019, 208-222

4) Memahami hukum Islam tentang zakat secara lebih mendalam dan hikmahnya serta mampu menerapkannya dalam perilaku sehari-hari.

5) Memahami hikmah haji dan umrah serta mampu menerapkannya dalam kehidupan sehari-hari.

6) Memahami hukum Islam tentang wakaf dan hikmahnya serta mampu menerapkannya dalam kehidupan sehari-hari.

7) Memahami hukum Islam tentang jual beli dan mampu menerapkannya dalam kehidupan sehari-hari.

8) Memahami hukum Islam tentang riba dan mampu menghindarinya dalam kehidupan sehari-hari.

9) Memahami hukum Islam tentang kerja sama ekonomi dan mampu menerapkannya dalam kehidupan sehari-hari.

10)Memahami ketentuan hukum penyelenggaraan jenazah dan mampu mempraktekkannya.

11) Memahami hukum Islam tentang jinayat dan hudud dan mampu menghindari kejahatan dalam kehidupan seharihari.

12)Memahami ketentuan tentang khutbah dan dakwah serta mampu mempraktekkannya.

13)Memahami hukum Islam tentang mawaris dan hikmahnya serta mampu menerapkannya dalam kehidupan sehari-hari.

14) Memahami hukum Islam tentang pernikahan dan hikmahnya serta mampu menerapkannya dalam kehidupan sehari-hari.

d) Akhlak

1) Terbiasa dengan perilaku dengan sifat-sifat terpuji.

2) Terbiasa menghindari sifat-sifat tercela.

3) Terbiasa bertata krama.

e) Tarikh

1) Memahami perkembangan Islam pada masa Umayyah dan mampu menerapkan manfaatnya dalam perilaku sehari-hari.

2) Memahami perkembangan Islam pada masa Abbasiyah dan mampu menerapkan manfaatnya dalam perilaku sehari-hari.

3) Memahami perkembangan Islam pada abad pertengahan dan mampu menerapkan manfaatnya dalam perilaku seharihari.

4) Memahami perkembangan Islam pada masa pembaharuan dan mampu menerapkan manfaatnya dalam perilaku seharihari.

5) Memahami perkembangan Islam di Indonesia dan mampu menerapkan manfaatnya dalam perilaku sehari-hari.

6) Memahami perkembangan Islam di dunia dan mampu menerapkan manfaatnya dalam perilaku sehari-hari. 


\section{c) Standar Kompetensi Pelajaran Umum}

Siswa dapat memahami keberadaan setiap individu dalam suatu negara, serta mengetahui segala hak dan kewajiban masing-masing. Dapat berbahasa Indonesia yang baik dan benar serta melengkapinya dengan bahasa Inggris dan Arab sebagai bahasa Internasional.

Setelah adanya program pemerintah yaitu kurikulum berbasis kompetensi (KBK) atau (competency based curriculum) dan disempurnakan menjadi KTSP (Kurikulum Tingkat Satuan Pendidikan) sebagai acuan dan pedoman bagi pelaksanaan pendidikan untuk mengembangkan berbagai ranah pendidikan (pengetahuan, keterampilan, dan sikap) dalam seluruh jenjang dan jalur pendidikan, khususnya pada jalur pendidikan sekolah, maka segala apa yang direncanakan dan diputuskan harus mengacu pada program tersebut.

Keberhasilan proses pembelajaran dinilai dari perubahanperubahan yang terjadi setelah belajar, yang mencakup pengetahuan atau wawasan, keterampilan (akademis dan social) dan sikap yang dapat dimanfaatkan peserta didik selama berada di bangku sekolah, untuk melanjutkan pendidikan pada jenjang yang lebih tinggi, dan mengembangkan diri di masyarakat sesuai denganasas pendidikan seumur hidup.

Mulyasa menyebutkan bahwa kompetensi dasar yang harus dimiliki oleha para siswa MA di pelajaran umum ${ }^{16}$ adalah:

1) Pengetahuan

Pengetahuan mencakup fakta, konsep, dan generalisasi. Fakta adalah data atau informasi tentang suatu benda atau peristiwa yang terjadi, misalnya tawuran pelajar, produk budaya seperti seni, perlengkapan hidup, dan alat transportasi. Konsep merupakan ide umum yang terbentuk dari sekumpulan fakta yang memiliki nilai dan sifat tertentu, misalnya budaya, perubahan social, modernisasi, dan korupsi. Generalisasi adalah pernyataan umum yang didasarkan pada teori dan menggambarkan hubungan di antara beberapa fakta, misalnya teori-teori tentang perubahan kebudayaan, dan teori penyimpangan perilaku.

2) Keterampilan

Keterampilan mencakup keterampilan akademis dan social. Keterampilan akademis sifatnya mulai dari mengingat, menafsirkan, menerapkan, menganalisis, mensintesis, sampai menilai. Keterampilan social dapat dilihat dari cara berkomunikasi dalam pergaulan, berhubungan dengan orang 
lain, memecahkan masalah, mengambil keputusan, bekerjasama, dan kemampuan kepemimpinan.

3) Sikap

Sikap dapat dilihat melalui cara berpikir dan bertindak yang mengacu pada nilai-nilai kesopanan, seperti kemampuan dalam menempatkan diri secara tepat pada situasi yang berbeda, dan respon terhadap berbagai fenomena yang terjadi.

Kompetensi actual yang dapat dikembangkan melalui pembelajaran pelajaran umum adalah:

a) Siswa dapat mengplikasikan isi pelajaran yang telah dipelajarinya.

b) Siswa dapat mengambil pelajaran dan menkonversikannya pada permasalah yang dihadapi di masyarakat.

c) Siswa dapat mendorong perubahan masyarakat dan kebudayaan beserta dampaknya (internal, eksternal, difisi, evolusi, akulturasi, kebudayaan popular, dan hibridisasi budaya).

\section{KESIMPULAN}

Sebagai model kurikulum Madrasah Aliyah, Kurikulum Terpadu (Integrated Curriculum) didasarkan pada pemecahan suatu problem, yakni "problem sosial" (social problem) yang dianggap penting dan menarik bagi anak didik perlu diterapkan. Pada tahap ini kesiapan emosionalnya sudah mulai mapan sehingga anak didik bisa mengaplikasikan ilmunya dalam pemecahan suatu problem yang ditemui.

Kurikulum terpadu ini disusun dari unit sumber (research unit) yang mencakup bahan (subject matter), kegiatan belajar (learning activity), dan sumber-sumber (resources) yang sangat luas. Sumber unit digunakan sebagai sumber untuk satuan pelajaran (learning unit) yang dipelajari anak didik di kelas. Perbedaan indvidual anak didik tidak harus selalu mempelajari hal-hal yang sama, dan ada kebebasan bagi anak didik untuk memiliki pelajaran menurut minat, bakat dan kemampuan mereka masing-masing. Dan agar Madrasah Aliyah tidak hilang ciri khasnya yang awal, maka pelajaran agama tetap dijadikan tolok ukur keberhasilan pendidikan dan pengajarannya. Sedangkan prosentase antara pelajaran agama dan umum dapat dimodifikasi sedemikian rupa dengan tanpa meninggalkan pelajaran pokok yang sudah menjadi kesepakatan bersama.

\section{DAFTAR PUSTAKA}

Ariatmi, SZ dan Prabawa, AH. 2002. Paradigma Pengembangan Kurikulum Pendidikan Tinggi tahun 2000. Surakarta: UMS. 
JURNAL PIWULANG, Vol. I No. 2 Maret 2019, 208-222

Idi, Abdullah. 1999. Pengembangan Kurikulum. Jakarta: GMP.

Mudjiono dan Dimyati. 2002. Belajar dan Pembelajaran. Jakarta: Rineka Cipta.

Muhaimin. 2003. Arah Baru Pengembangan Pendidikan Islam: Pemberdayaan, Pengembangan Kurikulum hingga Redefinisi Islamisasi Pengetahuan. Bandung: Nuansa.

Mulyasa, E. 2003. Kurikulum Berbasis Kompetensi: Konsep, Karakteristik, dan Implementasi. Bandung: Rosda.

Rahim, Husni. 2001. Arah Baru Pendidikan Islam di Indonesia. Jakarta:Logos.

Sujana, Nana. 1989. Dasar-dasar Proses Belajar Mengajar. Bandung: Sinar Baru.

Undang-undang Republik Indonesia No. 20 Tahun 2003, Tentang Sistem Pendidikan Nasional (SISDIKNAS).

http://sumberdaya.ristekdikti.go.id/index.php/2018/01/30/era-revolusiindustri- 4-0-saatnya-generasi-millennial-menjadi-dosen-masa-depan/ https://kbbi.web.id/unggul 